\title{
Population status of Bupleurum aureum (Apiaceae), a Critically Endangered plant species in a region of European Russia
}

\author{
Gennadiy G. Chugunov ${ }^{1}$, Anatoliy A. Khapugin ${ }^{2,3, *}$ \\ ${ }^{1}$ National Research Mordovia State University. Bolshevistskaya Street 68, Saransk, Republic of Mordovia, Russia \\ ${ }^{2}$ Joint Directorate of the Mordovia State Nature Reserve and National Park "Smolny", Dachnyi Lane 4, Saransk, \\ Republic of Mordovia, Russia \\ ${ }^{3}$ Tyumen State University, Lenina str. 25, 625000, Tyumen, Russia \\ *e-mail: hapugin88@yandex.ru
}

Received: 22 October 2019 / Accepted: 10 December 2019

\begin{abstract}
Protected Areas are considered as an important and widely applied tool for biodiversity conservation. They are especially relevant for conservation of threatened species populations. This paper presents study aimed to investigate population status and suitability of habitat conditions of a regionally Critically Endangered plant species, Bupleurum aureum (Apiaceae). Our research has been conducted in National Park "Smolny" (European Russia). The field studies were carried out in 2008, 2013-2018 in two study sites (Plot1, Plot2). In each study sites, square plots $(1 \times 1 \mathrm{~m})$ were established to cover the most number of $B$. aureum individuals. The population status was assessed on the basis of the morphometric traits of individuals (height of generative individuals, number of umbellulas per umbella, number of schizocarpiums per umbellula), number of individuals per population, age structure of populations, composition of accompanying flora. We analysed relationships between environmental conditions (shadiness, soil moisture, salt regime of soil, soil nitrogen, soil $\mathrm{pH}$, soil moisture variability) and morphometric and population traits of $B$. aureum to reveal the most influencing environmental factors. We found that at the north-western limit of the range, $B$. aureum has relatively low abundance and height of individuals in compare to available data from other parts of its range. The population age structure indicated higher habitat suitability in Plot1 due to presence of both vegetative and generative individuals. At the same time, in Plot2, $B$. aureum population is under serious threat due to a lack of vegetative individuals noted during almost whole study period. We suppose a forthcoming threat of probable loss of this $B$. aureum population. Environment data obtained in both habitats of $B$. aureum populations in National Park "Smolny" (Russia) indicated high relationships between soil moisture and the number of inflorescences formed by plants. We suppose a threat of extinction of the B. aureum population due to the building activity of Castor fiber inhabiting the small river Bakhmustika located nearby of study area. If the small river will be dammed, it could lead to decrease in $B$. aureum population in both studied sites due to the increase in ground water level.
\end{abstract}

Key words: environmental factor, Golden thoroughwax, morphological trait, plant population, Protected Area, Republic of Mordovia.

\section{Introduction}

Understanding the ecological and population characteristics of locally rare and/or threatened taxa not only enhances an understanding of population dynamics, adaptation and evolution, but also provides relevant actual data for biological conservation (Hedrick \& Miller, 1992; Puchnina, 2017; Samson \& Ramakrishnan, 2018). The size, structure, and dynamics trend of a population are the fundamental indicators of the fate in any plant population (Virillo et al., 2011). Rare and threatened plants often tend to have small or declined populations posing them vulnerable to environmental and anthropogenic threats (e.g. Zang et al., 2016). Other threats to plant species in wild are the population location on limits of species' range or inhabitation in unstable substrates. An evaluation of the current population 
status of threatened species and, in particular, characteristics affecting survival and reproduction in various habitats is a necessary condition for successfully preventing their extinction (Nurfadilah, 2017; Sudarmono, 2018). It makes especially relevant the population studies of the rare, threatened plants (e.g. Khapugin et al., 2016a; Zang et al., 2016; Fakhry et al., 2019), global and sub-global IUCN estimation of their status (Sérgio et al., 2007; Mounce et al., 2017) and forthcoming analysis of its results (Saiz et al., 2015; Gjerde et al., 2018; Kestemont, 2019).

Bupleurum aureum Fisch. ex Hoffm. is a perennial plant, 50 to $120 \mathrm{~cm}$ high, with short creeping rhizome. Leaves are large, wide elliptical, basal and lower cauline with long petiole. Umbellules are 15- to 20-flowered, 6 to 10 per umbel. Fruits are oblong or ellipsoid, 4.0 to $6.0 \mathrm{~mm}$ long, and 2.5 to $3.0 \mathrm{~mm}$ wide (Pan, 2006). It is an Eurasian plant species confined to open forests, forest edges, among shrubs, mountain slopes, river banks, rarer - it inhabits floodplain meadows in the Central and Eastern Europe, Kazakhstan, Kirghizstan, Mongolia, Western China (Sheh \& Watson, 2005; Pimenov \& Ostroumova, 2012). Bupleurum aureum is often studied in terms of chemical compounds (e.g. Naboka et al., 2014; Glushchenko et al., 2015), and successfully stored in botanical gardens (e.g. Galkina \& Zueva, 2018) with successful seed formation. However, despite of the wide native range of the plant species, there is a considerable lack of data on the status of B. aureum populations. In the Republic of Mordovia (European Russia), B. aureum is located at the north-western limits of its native range. In the region, it is considered as a rare species included in the regional Red Data Book with rarity category 2 (vulnerable species) (Silaeva, 2017). According to IUCN Guidelines and Criteria, B. aureum was estimated as regionally Critically Endangered species in the Republic of Mordovia (Khapugin et al., 2017).

Considering such threatened status and a lack of published data on $B$. aureum populations through the whole native range, we aimed to study population status and habitat suitability of this species in the National Park "Smolny" as an only B. aureum location of in the Republic of Mordovia. We addressed following questions: (i) What is the current trend of $B$. aureum population dynamics in Central Russia? (ii) What are the main threats to B. aureum populations in natural forest ecosystems of Central Russia?

\section{Study area}

National Park "Smolny" (NPS) is located in North-Eastern Mordovia (Central Russia), 54.72 ${ }^{\circ}-54.88^{\circ} \mathrm{N}, 45.07^{\circ}-$ $45.62^{\circ} \mathrm{E}$ (Fig. 1). It covers $363.86 \mathrm{~km}^{2}$. Pinus sylvestris L. is the main forest-forming species in southern part of NPS,

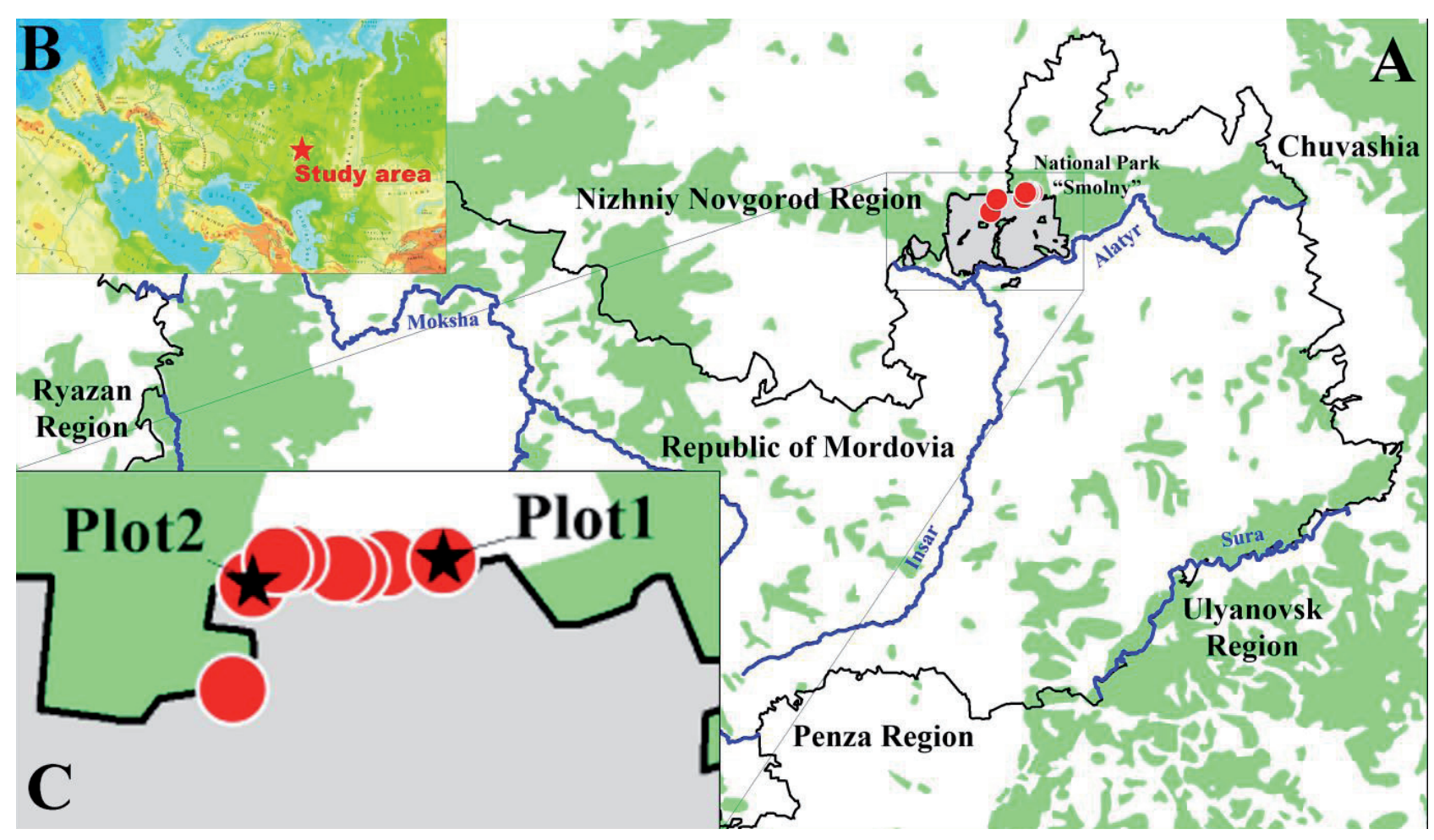

Figure 1. Location of National Park "Smolny" and study plots in the Republic of Mordovia (A) and Europe (B). Study plots are indicated by stars $(\mathrm{C})$ 
whereas broadleaf forests cover its northern part with domination of Quercus robur L., Tilia cordata Mill., Acer platanoides L., rarely - Fraxinus excelsior L. and Ulmus spp. Betula pendula Roth forms secondary (appeared after cut pine forests) forest communities mainly in southern part of NPS, while Populus tremula L. secondary (appeared after cut $Q$. robur and $T$. cordata forests) forests are distributed in the northern part of NPS. Picea abies L. does not form self-sustainable forests. Alnus glutinosa (L.) Gaertn. forms small forest areas in floodplains of river Alatyr and its main tributaries, nearby of eutrophic mires, and water bodies (Yamashkin et al., 2000).

\section{Material and methods}

The field investigations were carried out in 2008, 20132018 to study two the most stable populations in the National Park "Smolny" (Plot1 (quarter 4, Alexandrovskoe forestry, forest glade adjacent to the narrow clearing, on which undergrowth was eliminating during forest management actions) - 54.884860 N, 45.505161 E, Plot2 (quarter 3 , Alexandrovskoe forestry, an area recovering after cutting of 15 years old ago (by 2008)) - 54.883033 N, 45.480056 E). For field population-based investigations, five square plots $(1 \times 1 \mathrm{~m})$ were established in each location to cover the most number of individuals of threatened plant.

We estimated the $B$. aureum populations' status on the basis of the morphometric traits of individuals (height of generative individuals, number of umbellas per stem, number of umbellulas per umbella, number of schizocarpium (hereafter - seeds) per umbellula), number of individuals per population (except of 2008), age structure of populations (ratio and composition of age classes of individuals), composition of accompanying flora (studied in 2008, 2013-2016).

Age structure of $B$. aureum populations was determined by distinguishing all plants to vegetative (v) (non-flowering plants) and generative (g) (flowering plants) individuals. We compared age structure of both populations studied in National Park "Smolny".

The nomenclature and taxonomy of all the plants are presented in accordance with The Plant List (2013) and Euro+Med Plantbase (Euro+Med, 2006+). Jaccard's similarity index was calculated, where $A=$ number of species in locality $A ; B=$ number of species in locality $B ; C=$ number of species shared between two $(A$ and $B$ ) localities (Jaccard, 1901).

On the basis of the accompanying flora composition, environment factors were estimated in habitats with $B$. aureum in conditions of Mordovia. Environmental conditions were estimated according to Tsyganov (1983) ecological scales, where environmental indicator values (EIV) are arranged as interval scales. It means that for each plant spe- cies we can define the range of its existence in relation to concrete factor, for instance, soil nitrogen, moisture etc. It could be evaluated in conventional units covering the total factor longitude from minimum up to maximum in relation to concrete species. Mean EIVs were calculated using algorithm suggested by Buzuk \& Sozinov (2009). Taking into account results of different authors (Cui et al., 2009; Khapugin, 2017, 2019; Popov, 2017a, b), we used six environmental factors (shadiness (LC according to Tsyganov, 1983), soil moisture (HD), salt regime of soil (TR), soil nitrogen $(\mathrm{N})$, soil $\mathrm{pH}(\mathrm{RC})$, soil moisture variability $(\mathrm{FH})$ ), which have the most influence to status of plant populations at a local scale.

We tested correlation rate between morphometric and population traits of $B$. aureum and EIV values. The correlation coefficients were estimated according to Chaddock scale (Hinkle et al., 2003). The significant correlations $(\mathrm{p}<0.05)$ were visualised using XY graph plots. To analyze and visualise the relationships between used EIVs and population traits of B. aureum, we used Canonical correspondence analysis (CCA). We used Pearson's correlation analysis to estimate the relationships between the dependent (height of generative individuals, number of seeds per umbellula, number of umbellulas per umbella, number of vegetative and generative individuals per plot) and independent (shadiness (LC), salt regime of soil (TR), soil moisture (HD), soil pH (RC), soil nitrogen (NT), soil moisture variation(FH)) variables. Statistical analyses were carried out using PAST (Hammer et al., 2001) and Microsoft Excel.

\section{Results and discussion}

\subsection{Flora accompanying to Bupleurum aureum in study area}

As a result of 2008, 2013-2016 research, in flora accompanying to $B$. aureum, we identified 41 species in Plot1 and 48 species in Plot2 (Appendix). In general, it is represented by plant species of temperate deciduous forests (e.g., Aegopodium podagraria L., Carex pilosa Scop., Melica nutans L.), although some species were representatives of meadow (e.g., Trifolium montanum L., Potentilla norvegica L.) or forest-meadow flora (e.g., Trollius europaeus L., Rosa majalis Herrm.). Jaccard similarity index showed 48.3\% similarity between these floristic lists. It suggests moderate similarity of natural conditions in both study sites. Data on floristic composition in both sites were used to identify averaged EIVs as environmental indicators of habitat conditions (Table 1). 
No significant differences $(\mathrm{p}>0.05)$ were demonstrated between Plot1 and Plot2 in terms of environmental factors excepting of soil $\mathrm{pH}\left(\chi^{2}=4.45, \mathrm{p}<0.01\right)$. EIVs of soil moisture in both plots corresponded to regime of moist forest-meadow habitats. This is in consistent with EIV data on illumination, corresponding to regime of light forest group, and soil moisture variation corresponding to regime of relatively constant soil moisture. Data on soil nitrogen and salt regime of soil corresponded to habitat with relatively nitrogen-rich and salt-rich soils. Despite of significant difference between both Plot1 and Plot2 in soil pH, both study sites characterised by relatively acid soils with $\mathrm{pH}$ about 5.1-5.5 counted according to Tsyganov (1983). Thus, environmental conditions of $B$. aureum habitats in National Park "Smolny" correspond to light deciduous forests on nitrogen-rich and relatively moistened soils.

\subsection{The morphometric traits of Bupleurum aureum individuals and population characteristics}

The age structure of $B$. aureum population in both study sites (Fig. 2) demonstrated vegetatively oriented popula- tion type in Plot1 and generatively oriented population type in Plot2. Noteworthy, that vegetative individuals were almost absent in Plot2, as only one vegetative individual was found in this study site (in 2014) during the whole study period. It could be a serious threat for the further surviving of the aging $B$. aureum population in Plot2 due to an absence of vegetative plants. In contrary, in Plot1, B. aureum population was characterised by a sufficient number of both generative and vegetative individuals. We believe, that such proportion of $\mathrm{g}: \mathrm{v}$ individuals indicates a high viability of this population in the National Park "Smolny", because seed and vegetative reproduction are obviously observed here.

The height of $B$. aureum didn't differ significantly between both sites (Fig. 3). During all study years, it varied from $71 \mathrm{~cm}$ to $121.4 \mathrm{~cm}(93.9 \pm 5.6 \mathrm{~cm}$ in average $)$ in Plot1 and from $65.3 \mathrm{~cm}$ to $110 \mathrm{~cm}(95.5 \pm 6.4 \mathrm{~cm}$ in average) in Plot2. Our results showed lower height values than in Pre-Urals region, where $B$. aureum formed higher (from $64 \mathrm{~cm}$ to $134 \mathrm{~cm}$ ) generative individuals (Mingazheva, 2006). Kubentayev et al. (2018) found slightly higher values of height in generative $B$. aureum individuals

Table 1. Mean environmental indicator values in two Bupleurum aureum locations in the National Park "Smolny" on the basis of Tsyganov (1983) scales

\begin{tabular}{|c|c|c|c|c|c|c|}
\hline Year & HD & TR & NT & RC & $\mathbf{L C}$ & FH \\
\hline \multicolumn{7}{|c|}{ Plot1 } \\
\hline 2008 & 12.9 & 6.3 & 5.9 & 6.4 & 4.7 & 2.5 \\
\hline 2013 & 12.6 & 5.9 & 5.9 & 6.4 & 4.5 & 3.0 \\
\hline 2014 & 12.7 & 6.0 & 6.2 & 6.5 & 4.5 & 2.6 \\
\hline 2015 & 12.3 & 6.2 & 5.6 & 6.8 & 4.6 & 2.9 \\
\hline 2016 & 12.3 & 6.2 & 5.6 & 6.8 & 4.6 & 2.9 \\
\hline Mean & 12.6 & 6.1 & 5.9 & 6.6 & 4.6 & 2.8 \\
\hline \multicolumn{7}{|c|}{ Plot2 } \\
\hline 2008 & 12.3 & 6.4 & 5.7 & 6.8 & 4.5 & 2.6 \\
\hline 2013 & 13.2 & 6.2 & 5.4 & 7.1 & 4.6 & 2.4 \\
\hline 2014 & 12.7 & 6.3 & 6.8 & 7.1 & 4.9 & 2.4 \\
\hline 2015 & 12.3 & 6.0 & 5.5 & 7.1 & 4.5 & 3.0 \\
\hline 2016 & 11.9 & 6.5 & 5.5 & 7.0 & 4.0 & 3.2 \\
\hline Mean & 12.5 & 6.2 & 5.8 & 7.0 & 4.5 & 2.7 \\
\hline $\begin{array}{l}\text { Max. amplitude of EIVs } \\
\text { according to Tsyganov (1983) }\end{array}$ & $1-23$ & $1-19$ & $1-11$ & $1-13$ & $1-9$ & $1-11$ \\
\hline
\end{tabular}

Note: Original designations of EIVs in Tsyganov (1983): LC - shadiness, TR - salt regime of soil, HD - soil moisture, RC - soil $\mathrm{pH}, \mathrm{NT}$ - soil nitrogen, $\mathrm{FH}$ - soil moisture variation. 


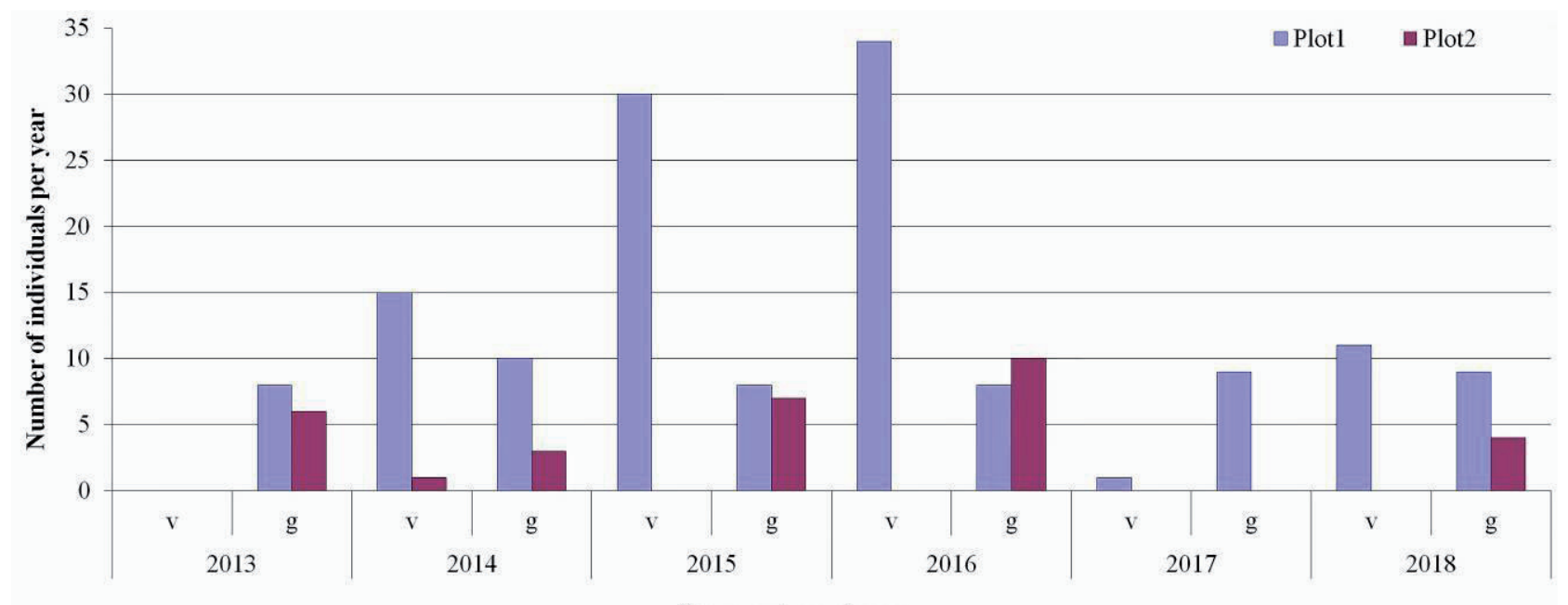

Years and age classes

Figure 2. The changes in age structure of Bupleurum aureum populations during 2008, 2013-2018 in two study sites in the National Park "Smolny" (Russia). Designations: v - vegetative individuals, g - generative individuals

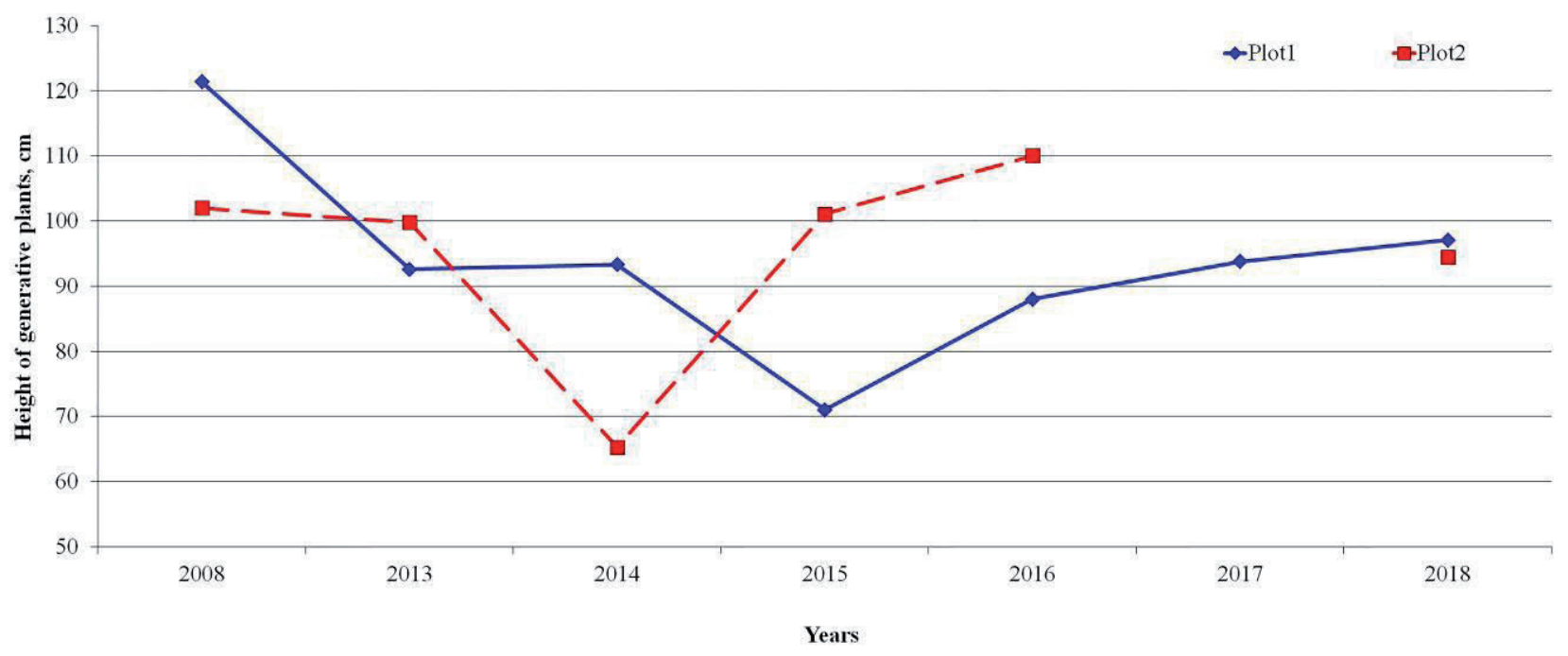

Figure 3. The changes in height of generative individuals of Bupleurum aureum during 2008, 2013-2018 in two study sites in the National Park "Smolny" (Russia)

$(105 \pm 13.5 \mathrm{~cm}$ in average with variation from $55.4 \pm 1.1$ $\mathrm{cm}$ to $133.1 \pm 6.1 \mathrm{~cm}$ ) in Eastern Kazakhstan, than we found in the National Park "Smolny". Our results are more similar with data obtained in the North of European Russia, where fruiting individuals reached $95.5 \pm 4.4 \mathrm{~cm}$ in average with variation from $86 \mathrm{~cm}$ to $107 \mathrm{~cm}$ (Echishvili \& Portnyagina, 2015). Most probably, similar results are explained by the peripheral (i.e. at the range limits) location of B. aureum populations in both Komi Republic and Republic of Mordovia.
Study of morphometric traits of $B$. aureum individuals found at study sites in 2008, 2013-2018 demonstrated fluctuations in number of seeds produced per umbellula (Fig. 4). Its peak was observed in 2014-2015 followed by decline of its parameter in 2016 with the further increase. Noteworthy, an increase in seed number produced per umbellula was accompanied by decline in number of umbellula per umbella. Fig. 4 showed that averaged seed productivity was 2.7-14.8 seeds per umbellula in both study sites. It could be considered as very high values taking into 


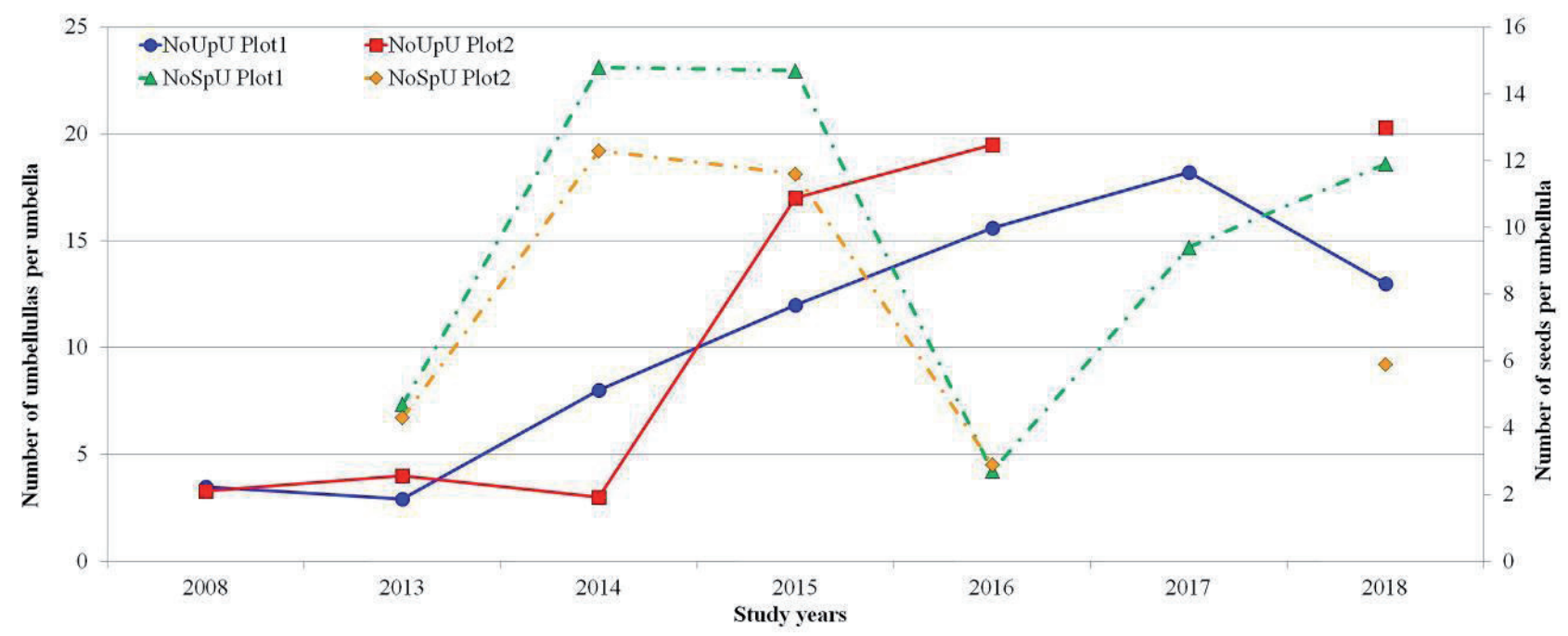

Figure 4. The dynamics in number of umbellulas per umbella (NoUpU) (left $\mathrm{Y}$ axis) and number of seeds produced per umbellula (NoSpU) (right Y axis) of Bupleurum aureum during 2008, 2013-2018 in two study sites in the National Park "Smolny" (Russia)

account that $B$. aureum has typically 15-20 flowers per umbellula (Podgaevskaya, 2002; Pan, 2006).

\subsection{Relations between environment and plant population traits}

To reveal relationships between tested environmental factors and morphometric and population traits of B. aureum, we conducted canonical component analysis (CCA) (Fig. 5), where environmental factors (according to Tsyganov, 1983) acted as environmental variables. Noteworthy, environment conditions were similar at the first years of the study $(2008,2013)$, when both populations were under influence of moderate human pressure. So, Plot1 was located nearby of managed narrow clearing, while Plot2 was located in forest community recovering after cutting off of about 12 years before 2008. During the following study years (2013-2016), in site Plot2, environment conditions became obviously different of site Plot1 due to natural recovery of forest community. In contrary, in site Plot1, environment conditions were maintaining permanent because of the forest management actions aimed to cutting the undergrowth at the narrow clearing located nearby. In Plot1 (Fig. 5), the habitat illumination and soil moisture in forest community were decreasing during the study period according to direction of biplot arrows. Obviously, it was caused by undergrowth development, causing changes in flora and vegetation in different ecosystems (e.g. Khapugin et al., 2016b; Yang et al., 2018). At the same time, anthropogenically maintained conditions of Plot2 did not differ significantly between study years (Fig. 5). Taking into account phytoindication data of Tsyganov (1983) scales, Fig. 5 demonstrated similar environmental conditions in both B. aureum habitats in 2008 , followed by their forthcoming distinguishing caused, probably, by natural succession in site Plot1.

Because of relationships between different environmental variables are already known (e.g. Butterbach-Bahl et al., 2013; Fan et al., 2015; Justine et al., 2017), we focused on relationships between environmental factors and morphometric and population traits of $B$. aureum, as well as between different morphometric and population parameters. Table 2 demonstrated an absence of very high correlation between environmental and dependent variables. We found high significant correlation between soil moisture and number of umbellulas per umbella (negative, $p=0.015)$ and between habitat shadiness and soil moisture variation (positive, $\mathrm{p}=0.005$ ). The moderate significant correlation coefficients were recorded between height of generative plants and number of seeds produced by an umbellula (negative, $\mathrm{p}=0.033$ ). Cases of significant correlation $(\mathrm{p}<0.05)$ are presented in Fig. 6.

Our correlation analysis showed low correlation coefficients between environmental factors and morphometric and population parameters in B. aureum habitats. Fig. 6 demonstrated significant correlations only between number of umbellulas per umbella and soil moisture and soil moisture variation. It underlines a leading role of soil moisture regime in a habitat to support $B$. aureum surviving in the National Park "Smolny". Our assumption is confirmed by data stated that water is considered as a leading factor determining structure and dynamics of plant communities (Ferreira et al., 2007; Zhu et al., 2014; Khapugin et al., 2018).

Among other environmental factors demonstrated moderate correlations with low significance, we can indicate habitat illumination and soil nitrogen. These factors were considered as leading determinants of habitat suitability for 


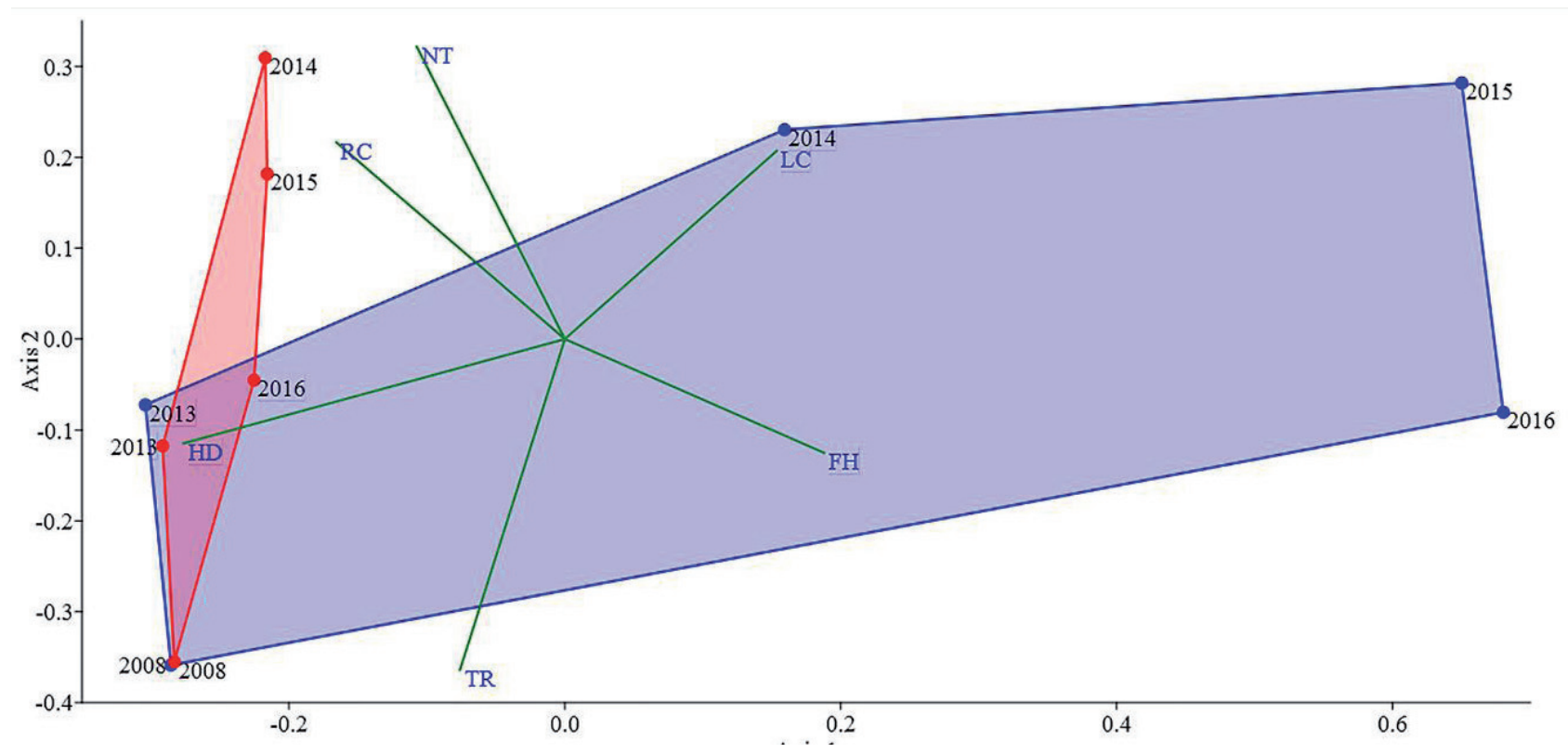

Figure 5. Canonical correspondence analysis (CCA) ordination diagram with data from Plot1 (blue dots) and Plot2 (red dots), and environmental indicator values as variables (biplot arrows); first axis is horizontal, second axis is vertical. The involved years are 2008, 2013, 2014, 2015, 2016. The environmental indicator variables according to Tsyganov (1983) scales are: LC - shadiness, TR - salt regime of soil, HD - soil moisture, RC - soil pH, NT - soil nitrogen, FH - soil moisture variation

Table 2. Correlation and p-values matrix of the environmental indicator values and morphometric and population traits of Bupleurum aureum in the National Park "Smolny" (method - Pearson)

\begin{tabular}{|c|c|c|c|c|c|c|c|c|c|c|c|}
\hline & HD & TR & NT & RC & LC & FH & HoGP & NoUpU & NoSpU & v & g \\
\hline HD & & 0.411 & 0.386 & 0.727 & 0.026 & 0.005 & 0.974 & 0.015 & 0.979 & 0.521 & 0.344 \\
\hline TR & -0.293 & & 0.911 & 0.269 & 0.410 & 0.818 & 0.523 & 0.720 & 0.194 & 0.799 & 0.309 \\
\hline NT & 0.309 & -0.041 & & 0.451 & 0.118 & 0.094 & 0.229 & 0.122 & 0.360 & 0.786 & 0.430 \\
\hline RC & -0.127 & 0.387 & -0.270 & & 0.823 & 0.724 & 0.668 & 0.370 & 0.808 & 0.560 & 0.961 \\
\hline LC & $0.693^{*}$ & -0.294 & 0.527 & -0.082 & & 0.027 & 0.1700 & 0.099 & 0.448 & 0.628 & 0.214 \\
\hline FH & $-0.811 *$ & 0.084 & -0.558 & -0.128 & $-0.692 *$ & & 0.391 & 0.019 & 0.534 & 0.662 & 0.268 \\
\hline HoGP & 0.012 & 0.230 & -0.418 & -0.156 & -0.471 & 0.306 & & 0.841 & 0.033 & 0.166 & 0.561 \\
\hline NoUpU & $-0.739 *$ & 0.130 & -0.522 & 0.318 & -0.550 & $0.721 *$ & 0.073 & & 0.667 & 0.280 & 0.054 \\
\hline NoSpU & 0.010 & -0.448 & 0.325 & 0.089 & 0.271 & -0.224 & $-0.672 *$ & 0.156 & & 0.383 & 0.192 \\
\hline $\mathbf{v}$ & -0.231 & -0.093 & -0.099 & -0.210 & 0.176 & 0.159 & -0.474 & 0.379 & 0.310 & & 0.243 \\
\hline $\mathbf{g}$ & -0.335 & -0.359 & -0.282 & -0.018 & -0.431 & 0.388 & -0.210 & 0.625 & 0.450 & 0.407 & \\
\hline
\end{tabular}

Note: Linear $\mathrm{r}$ (Pearson) values are below diagonal, $\mathrm{p}$ values are above diagonal. Cells with high positive (negative) correlation are in dark gray; cells with moderate positive (negative) correlation are in light gray. Designations: LC - shadiness, TR - salt regime of soil, HD - soil moisture, RC - soil pH, NT - soil nitrogen, FH - soil moisture variation, HoGP - height of generative plants, NoUpU - number of umbellulas per umbella, NoSpU - number of seeds formed by umbellula, $\mathrm{v}-$ vegetative individuals, $g$ generative plants; asterisk indicates significant values $(\mathrm{p}<0.05)$. 

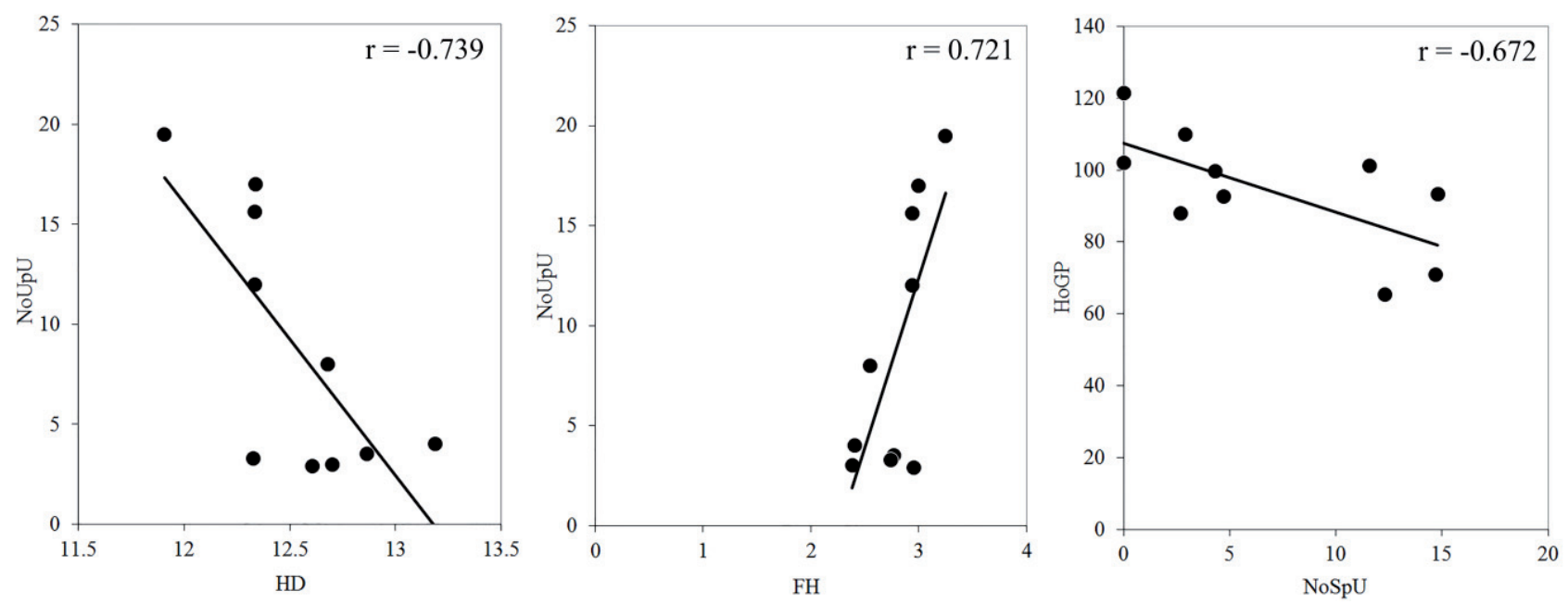

Figure 6. The correlations between the number of umbellulas per umbella (NoUpU) and Tsyganov's environmental indicator values $\left(\mathrm{HD}\right.$ - soil moisture $\left(\mathrm{R}^{2}=0.546, \mathrm{y}=-13.624 \mathrm{x}+179.55\right), \mathrm{FH}-$ soil moisture variation $\left(\mathrm{R}^{2}=0.520, \mathrm{y}=17.032 \mathrm{x}-\right.$ $38.713)$ ), and between height of generative plants (HoGP) and number of seeds formed by umbellula (NoSpU) $\left(\mathrm{R}^{2}=0.451\right.$, $y=-1.9093 x+107.43)$ in Bupleurum aureum populations during 2008, 2013-2016 in the National Park "Smolny" (Russia)

another plant species or ecosystems as a whole (Kotowski \& Diggelen, 2004; Seregin, 2014; Hrivnak et al., 2015; Skrzypek et al., 2015). Perhaps, their small influence on traits of $B$. aureum population could be explained by biological preferences of the threatened species.

\section{Conclusions}

The conducted population-based studies of B. aureum at the north-western limit of its range demonstrated relatively low abundance of individuals in both habitats investigated. Generative individuals were lower than B. aureum plants in some other parts of the range. We found that age structure of the threatened plant in one site (Plot2) indicated favourable conditions due to appropriate number of both vegetative and generative individuals, while, in Plot1, $B$. aureum population was under serious threat due to a lack of vegetative individuals during almost ten study years. We suppose the local extinction of this population or its transition to a rest state in future.

The development of conservation plant for any threatened species needs obtaining a large amount of information about a target species, as well as about habitat conditions and, if possible, local dynamics of environmental factors. Data obtained for B. aureum population in the National Park "Smolny" indicated high correlation between soil water and the number of inflorescences formed per plant. This could threaten further survive of the B. aureum population in the National Park "Smolny" due to the building activity of Castor fiber Linnaeus, 1758 on the small river
Bakhmustika located nearby of both study sites (personal observations, 2013-2019). The found negative correlation between inflorescences' number and soil water allows us to suppose the future decline in $B$. aureum population due increase in ground water level affected by damming of small river Bakhmustika.

\section{Acknowledgement}

We are grateful to two anonymous reviewers for their constructive comments and feedback on an earlier version of this paper.

\section{References}

Butterbach-Bahl K., Baggs E.M., Dannenmann M., Kiese R. \& Zechmeister-Boltenstern S., 2013, Nitrous oxide emissions from soils: how well do we understand the processes and their controls? Philosophical Transactions of the Royal Society B 368: 2013.01.22. (http:// dx.doi.org/10.1098/rstb.2013.0122).

Buzuk G.N. \& Sozinov O.V., 2009, Regression analysis in phytoindication (on example of D.N. Tsyganov's ecological scales), [in:] Botany (research): Proceedings, Minsk: Pravo i Ekonomika 37: 356-362 [in Russian]. Cui B.S., Zhai H.J., Dong S.K., Chen B. \& Liu S.L., 2009, Multivariate analysis of the effects of edaphic and topographical factors on plant distribution in the Yilong lake basin of Yun-Gui Plateau, China. Cana- 
dian Journal of Plant Science 89(1): 209-219. (http:// dx.doi.org/10.4141/CJPS08013).

Echishvili E. \& Portnyagina N., 2015, Developmental biology thoroughwax gold in a middle taiga subzone of the Komi Republic. Vestnik Insituta Biologii Komi NC UrO RAN 6(194): 4-6 [in Russian]

Euro+Med, 2006+, Euro+Med PlantBase - the information resource for Euro-Mediterranean plant diversity. (http://ww2.bgbm.org/EuroPlusMed/).

Fakhry A.M., El-Keblawy A., Shabana H.A., Gamal I.E. \& Shalouf, A. 2019, Microhabitats Affect Population Size and Plant Vigor of Three Critically Endangered Endemic Plants in Southern Sinai Mountains, Egypt. Land 8(6): 86. (http://dx.doi.org/10.3390/ land8060086).

Fan L.C., Yang M.Z. \& Han, W.Y., 2015, Soil respiration under different land uses in Eastern China. PloS ONE 10(4): e0124198. (http://dx.doi.org/10.1371/journal. pone.0124198).

Ferreira J.N., Bustamante M., Garcia-Montiel D.C., Caylor K.K. \& Davidson E.A. 2007, Spatial variation in vegetation structure coupled to plant available water determined by two-dimensional soil resistivity profiling in a Brazilian savanna. Oecologia. 153: 417-430. (http://dx.doi.org/10.1007/s00442-007-0747-6).

Galkina M.A. \& Zueva M.A., 2018, Collection «Flora of Siberia» in the Main Botanical Garden of RAS (Russia). Nature Conservation Research 3(1): 65-79. (http://dx.doi.org/10.24189/ncr.2018.009).

Gjerde I., Grytnes J.-A., Heegaard E., Sætersdal M. \& Tingstad L., 2018, Red List updates and the robustness of sites selected for conservation of red-listed species. Global Ecology and Conservation 16: e00454.

Glushchenko A.V., Perekhoda L.A. \& Georgiyants V.A., 2015, Docking studies of the chemical components of the composition of Bupleurum aureum plant in relation to hepatoprotective biotargets. Der Pharma Chemica 7(4): 201-206.

Hammer Ø., Harper D.A.T. \& Ryan P.D., 2001, PAST: Paleontological statistics soft-ware package for education and data analysis. Palaeontologia Electronica 4(1): 1-9.

Hedrick P.W. \& Miller P.S., 1992, Conservation genetics: techniques and fundamentals Ecological Applications 2: $30-46$.

Hinkle D.E., Wiersma W. \& Jurs S.G., 2003, Applied Statistics for the Behavioral Sciences. 5th Edition. Houghton Mifflin Harcourt, Boston: 1-792.

Hrivnak R., Slezak M., Jarcuska B., Jarolimek I. \& Kochjarova J., 2015, Native and alien plant species richness response to soil nitrogen and phosphorous in temperate floodplain and swamp forest. Forests 6: 35013513. (http://dx.doi.org/10.3390/f6103501).
Jaccard P., 1901, Etude comparative de la distribution florale dans une portion des Alpes et du Jura. Bulletin de la Societe Vaudoise des Sciences Naturelles 37 : 547-549.

Justine M.F., Yang W., Wu F., Tan B., Naeem Khan M. \& Li Z., 2017, Dissolved organic matter in soils varies across a chronosequence of Pinus massoniana plantations. Ecosphere 8(4): e01764. (https://dx.doi. org/10.1002/ecs2.1764).

Kestemont B., 2019, The bottom-up assessment of threatened species. Nature Conservation Research 4(3): 93-106. (https://dx.doi.org/10.24189/ ncr.2019.036).

Khapugin A.A., 2017, Hieracium sylvularum (Asteraceae) in the Mordovia State Nature Reserve: invasive plant or historical heritage of the flora? Nature Conservation Research 2(4): 40-52. (http://dx.doi.org/10.24189/ ncr.2017.013)

Khapugin A.A., 2019, Benefits from visualization of environmental factor gradients: a case study in a protected area in central Russia. Revista Chapingo Serie Ciencias Forestales y del Ambiente 25(3): 383-398. (http://dx.doi.org/10.5154/r.rchscfa.2019.01.004).

Khapugin A.A., Silaeva T.B., Vargot E.V., Chugunov G.G., Grishutkina G.A., Grishutkin O.G., Pismarkina E.V. \& Orlova Ju.S., 2017, Estimation of taxa included in the first volume of the Red Data Book of the Republic of Mordovia (Russia) using the IUCN Red List Categories and Criteria. Nature Conservation Research 2(Suppl.1): 164-189. (http://dx.doi. org/10.24189/ncr.2017.004).

Khapugin A.A., Chugunov G.G., Silaeva T.B. \& Kunaeva E.N., 2016a, Neottianthe cucullata (L.) Schltr. (Orchidaceae Juss.), an endangered orchid in Central Russia. Wulfenia 23: 189-202.

Khapugin A.A., Vargot E.V., Chugunov G.G. \& Shugaev N.I. 2016b. Invasion of alien plants in fire-damaged forests at Southern boundary of the taiga zone. Forest Systems 25(3): eSC13. (http://dx.doi.org/10.5424/ fs/2016253-09461).

Khapugin A.A., Kunaeva E.N. \& Silaeva T.B., 2018, Extreme drought conditions can drastically change age structure of a plant population: case study of Jacobaea paludosa subsp. lanata (Family: Asteraceae) in the Republic of Mordovia (Russia). Journal of Bombay Natural History Society 115: 21-24. (http://dx.doi. org/10.17087/jbnhs/2018/v115/116395).

Kotowski W. \& van Diggelen R., 2004, Light as an environmental filter in fen vegetation. Journal of Vegetation Science 15(5): 583-594. (http://dx.doi. org/10.1658/1100-9233(2004)015[0583:LAAEFI]2.0. $\mathrm{CO} ; 2)$.

Kubentayev S.A., Suleimenov A.N., Kotukhov J.A., Danilova A.N. \& Sumbembayev A.A., 2018, 
Phytocenotic characteristics and stocks of the main medicinal plants of the South-Western Altai (East Kazakhstan). Eurasian Journal of BioSciences 12: 355-368.

Mingazheva A.M., 2006, Bupleurum longifolium L. subsp. aureum (Fisch.) Soo. in the pre-Urals (biological features, introduction perspectives and biochemical composition). PhD Thesis Abstract, Moscow: 1-19 [in Russian].

Mounce R., Rivers M., Sharrock S., Smith P. \& Brockington S., 2017, Comparing and contrasting threat assessments of plant species at the global and sub-global level. Biodiversity and Conservation 27(4): 907-930. (http://dx.doi.org/10.1007/s10531-0171472-z).

Naboka, O.I., Samer K., Glushchenko A.V. \& Georgiyants V.A., 2014, Antioxidant properties of extracts of aerial part of Bupleurum aureum, hill-growing saltwort herb, Fumaria shleicheri and Cynara scolymus in vitro and in vivo. Journal of Chemical and Pharmaceutical Research 6(7): 172-177.

Nurfadilah S., 2017, Population study of Peristylus goodyeroides (Orchidaceae) in five habitats and implication for its conservation Biodiversitas 18(3): 1084-1091.

Pan S.L. (ed.), 2006, Bupleurum Species: Scientific Evaluation and Clinical Applications. CRC Press, Taylor and Francis Group, Boca Raton, USA: 1-272.

Pimenov M.G. \& Ostroumova T.A., 2012, Umbelliferae of Russia. KMK Scientific Press Ltd., Moscow: 1-484 [in Russian].

Podgaevskaya, E.N., 2002, Bupleurum aureum, [in:] L.A. Zhukova (ed.), Ontogenetic atlas of medicinal plants, Vol. 3, Mari El State University: Yoshkar-Ola: 120124 [in Russian].

Popov S.Yu., 2017a, Structure and features of spatial distribution of pine forests in the Pinega State Nature Reserve. Nature Conservation Research 2(1): 40-56. (http://dx.doi.org/10.24189/ncr.2017.055).

Popov S.Yu., 2017b. Vegetation of birch and aspen forests in the Pinega State Reserve. Nature Conservation Research 2(2): 66-83. (http://dx.doi.org/10.24189/ ncr.2017.015).

Puchnina L.V., 2017, Status of Calypso bulbosa and Cypripedium calceolus (Orchidaceae) populations in the Pinega State Nature Reserve. Nature Conservation Research 2(Suppl.1): 125-150. (http://dx.doi. org/10.24189/ncr.2017.023).

Saiz J.C.M., Lozano F.D., Gómez M.M. \& Baudet Á.B., 2015, Application of the Red List Index for conservation assessment of Spanish vascular plants. Conservation Biology 29(3): 910-919. (http://dx.doi. org/10.1111/cobi.12437).
Samson A. \& Ramakrishnan B., 2018, Population status, habitat selection and people's perception on Pavo cristatus (Aves: Phasianidae) in Sigur Plateau, the Nilgiris, Tamil Nadu, India. Nature Conservation Research 3(1): 80-87. (http://dx.doi.org/10.24189/ ncr.2018.010).

Seregin A.P., 2014, Further east: eutrophication as a major threat to the flora of Vladimir Oblast Russia. Environmental Science and Pollution Research 21: 12883-12897. (http://dx.doi.org/10.1007/s11356-0143152-9).

Sérgio C., Brugués M., Cros R.M., Casas C. \& Garcia C., 2007, The 2006 Red List and an updated checklist of bryophytes of the Iberian Peninsula (Portugal, Spain and Andorra). Lindbergia 31: 109-125. (http:// dx.doi.org/10.2307/20150218).

Sheh M. \& Watson M.F., 2005, Bupleurum, [in:] Z.Y. Wu \& P.H. Raven (eds.), Flora of China 14. Science Press, Beijing; Missouri Botanical Garden Press, St. Louis: 60-74.

Silaeva T.B. (ed.), 2017, Red Data Book of the Republic of Mordovia: in 2 vol., vol. 1: Rare species of plants and fungi, 2nd ed. Publisher of the Mordovia State University, Saransk: 1-409 [in Russian].

Skrzypek G., Wojtuń B., Richter D., Jakubas D., Wojczulanis-Jakubas K. \& Samecka-Cymerman A., 2015, Diversification of Nitrogen Sources in Various Tundra Vegetation Types in the High Arctic. PloS ONE, 10(9): e0136536. (http://dx.doi.org/10.1371/ journal.pone.0136536).

Sudarmono, 2018, Decreased populations of Scutellaria discolor and Plectranthus galeatus (Lamiaceae) on Mount Gede, West Java, Indonesian and its surrounding. Biodiversitas 19(5): 1866-1870.

The Plant List, 2013, Version 1.1. (Retrieved 05 December 2019 from http://www.theplantlist.org/).

Tsyganov D.N., 1983, Phytoindication of ecological regimes in the mixed coniferous-broad-leaved forest subzone. Nauka: Moscow: 1-197 [in Russian].

Virillo C.B., Martins F.R., Tamashiro J.Y. \& dos Santos F.A.M., 2011, Is size structure a good measure of future trends of plant populations? an empirical approach using five woody species from the Cerrado (Brazilian savanna). Acta Botanica Brasilica 25(3): 593-600. (http://dx.doi.org/10.1590/S010233062011000300012).

Yamashkin A.A., Silaeva T.B., Alba L.D., Dykov I.E., Moiseenko V.A., Revin V.V., Rybin Yu.I., Sviridov A.A. \& Talalaevskiy L.M. (eds.), 2000, Mordovia National Park "Smolny”. Saransk: 1-88 [in Russian]. Yang T., Ala M., Zhang Y., Wu J., Wang A. \& Guan D., 2018, Characteristics of soil moisture under different vegetation coverage in Horqin Sandy Land, northern 
China. PLoS ONE, 13(6): e0198805. (http://dx.doi. org/10.1371/journal.pone.0198805).

Zang R.G., Dong M., Li J.Q., Chen X.Y., Zeng S.J., Jiang M.X., Li Z.Q. \& Huang J.H., 2016, Conservation and restoration for typical critically endangered wild plants with extremely small population. Acta Ecologica Sinica 36(22): 7130-7135. (http://dx.doi. org/10.5846/stxb201610082011).
Zhu J.T., Yu J.J., Wang P., Yu Q. \& Eamus D., 2014, Variability in groundwater depth and composition and their impacts on vegetation succession in the lower Heihe River Basin, north-western China. Marine and Freshwater Research 65: 206-217. (http://dx.doi. org/10.1071/MF13082).

\section{Appendix}

Table. S1. List of plant species accompanying to Bupleurum aureum in the National Park "Smolny" (Russia)

\begin{tabular}{|c|c|c|c|}
\hline Species & Family & Plot1 & Plot2 \\
\hline Acer platanoides L. & Sapindaceae & $\mathrm{Y}$ & $\mathrm{Y}$ \\
\hline Achillea millefolium L. & Compositae & $\mathrm{N}$ & $\mathrm{Y}$ \\
\hline Clinopodium acinos (L.) Kuntze & Lamiaceae & $\mathrm{Y}$ & $\mathrm{Y}$ \\
\hline Aconitum septentrionale Koelle & Ranunculaceae & $\mathrm{Y}$ & $\mathrm{N}$ \\
\hline Aegopodium podagraria L. & Apiaceae & Y & $\mathrm{Y}$ \\
\hline Angelica sylvestris L. & Apiaceae & $\mathrm{Y}$ & $\mathrm{Y}$ \\
\hline Anthriscus sylvestris (L.) Hoffm. & Apiaceae & $\mathrm{Y}$ & $\mathrm{Y}$ \\
\hline Asarum europaeum L. & Aristolochiaceae & $\mathrm{Y}$ & $\mathrm{Y}$ \\
\hline Betula pendula Roth & Betulaceae & $\mathrm{Y}$ & Y \\
\hline Bromus inermis Leyss. & Poaceae & $\mathrm{N}$ & $\mathrm{Y}$ \\
\hline Calamagrostis epigeios (L.) Roth & Poaceae & $\mathrm{N}$ & $\mathrm{Y}$ \\
\hline Campanula persicifolia $\mathrm{L}$. & Campanulaceae & $\mathrm{N}$ & $\mathrm{Y}$ \\
\hline Campanula trachelium $\mathrm{L}$. & Campanulaceae & $\mathrm{Y}$ & Y \\
\hline Carex pilosa Scop. & Cyperaceae & $\mathrm{Y}$ & $\mathrm{Y}$ \\
\hline Centaurea phrygia L. & Compositae & $\mathrm{Y}$ & Y \\
\hline Dactylis glomerata L. & Poaceae & $\mathrm{Y}$ & $\mathrm{N}$ \\
\hline Daphne mezereum $\mathrm{L}$. & Thymelaeaceae & $\mathrm{N}$ & $\mathrm{Y}$ \\
\hline Equisetum sylvaticum L. & Equisetaceae & $\mathrm{Y}$ & $\mathrm{N}$ \\
\hline Euonymus verrucosus Scop. & Celastraceae & $\mathrm{Y}$ & $\mathrm{Y}$ \\
\hline Festuca gigantea (L.) Vill. & Poaceae & $\mathrm{Y}$ & $\mathrm{N}$ \\
\hline Filipendula ulmaria (L.) Maxim. & Rosaceae & $\mathrm{Y}$ & $\mathrm{N}$ \\
\hline Fragaria moschata (Duchesne) Duchesne & Rosaceae & $\mathrm{N}$ & Y \\
\hline Fragaria vesca L. & Rosaceae & $\mathrm{Y}$ & $\mathrm{Y}$ \\
\hline Frangula alnus Mill. & Rhamnaceae & $\mathrm{Y}$ & $\mathrm{Y}$ \\
\hline Galium verum $\mathrm{L}$. & Rubiaceae & $\mathrm{N}$ & $\mathrm{Y}$ \\
\hline Geranium sylvaticum L. & Geraniaceae & $\mathrm{Y}$ & $\mathrm{N}$ \\
\hline
\end{tabular}




\begin{tabular}{|c|c|c|c|}
\hline Species & Family & Plot1 & Plot2 \\
\hline Geum urbanum L. & Rosaceae & $\mathrm{Y}$ & $\mathrm{Y}$ \\
\hline Glechoma hederacea L. & Lamiaceae & $\mathrm{Y}$ & $\mathrm{Y}$ \\
\hline Hypericum perforatum $\mathrm{L}$. & Hypericaceae & $\mathrm{N}$ & $\mathrm{Y}$ \\
\hline Knautia arvensis (L.) Coult. & Caprifoliaceae & $\mathrm{Y}$ & $\mathrm{Y}$ \\
\hline Lamium maculatum (L.) L. & Lamiaceae & $\mathrm{Y}$ & $\mathrm{Y}$ \\
\hline Lathyrus vernus (L.) Bernh. & Leguminosae & $\mathrm{Y}$ & $\mathrm{Y}$ \\
\hline Lonicera xylosteum L. & Caprifoliaceae & $\mathrm{N}$ & $\mathrm{Y}$ \\
\hline Malus sylvestris (L.) Mill. & Rosaceae & $\mathrm{N}$ & $\mathrm{Y}$ \\
\hline Melampyrum nemorosum L. & Orobanchaceae & $\mathrm{Y}$ & Y \\
\hline Melica nutans $\mathrm{L}$. & Poaceae & $\mathrm{Y}$ & $\mathrm{N}$ \\
\hline Mercurialis perennis L. & Euphorbiaceae & $\mathrm{Y}$ & $\mathrm{Y}$ \\
\hline Prunus padus L. & Rosaceae & $\mathrm{Y}$ & $\mathrm{N}$ \\
\hline Pimpinella saxifraga $\mathrm{L}$. & Apiaceae & $\mathrm{N}$ & $\mathrm{Y}$ \\
\hline Poa nemoralis L. & Poaceae & $\mathrm{Y}$ & $\mathrm{Y}$ \\
\hline Populus tremula $\mathrm{L}$. & Salicaceae & Y & Y \\
\hline Potentilla norvegica $\mathrm{L}$. & Rosaceae & $\mathrm{N}$ & $\mathrm{Y}$ \\
\hline Primula veris $\mathrm{L}$. & Primulaceae & $\mathrm{N}$ & $\mathrm{Y}$ \\
\hline Pyrus communis L. & Rosaceae & $\mathrm{N}$ & $\mathrm{Y}$ \\
\hline Quercus robur L. & Fagaceae & $\mathrm{Y}$ & $\mathrm{Y}$ \\
\hline Ranunculus cassubicus L. & Ranunculaceae & $\mathrm{N}$ & $\mathrm{Y}$ \\
\hline Rosa majalis Herrm. & Rosaceae & $\mathrm{N}$ & $\mathrm{Y}$ \\
\hline Rubus saxatilis L. & Rosaceae & $\mathrm{Y}$ & $\mathrm{Y}$ \\
\hline Solidago virgaurea $\mathrm{L}$. & Compositae & $\mathrm{Y}$ & $\mathrm{N}$ \\
\hline Sorbus aucuparia L. & Rosaceae & $\mathrm{N}$ & $\mathrm{Y}$ \\
\hline Stachys sylvatica L. & Lamiaceae & $\mathrm{Y}$ & $\mathrm{N}$ \\
\hline Stellaria graminea L. & Caryophyllaceae & $\mathrm{N}$ & $\mathrm{Y}$ \\
\hline Stellaria holostea L. & Caryophyllaceae & Y & $\mathrm{Y}$ \\
\hline Tilia cordata Mill. & Malvaceae & $\mathrm{Y}$ & $\mathrm{Y}$ \\
\hline Trifolium montanum L. & Leguminosae & $\mathrm{N}$ & $\mathrm{Y}$ \\
\hline Trollius europaeus L. & Ranunculaceae & $\mathrm{Y}$ & $\mathrm{Y}$ \\
\hline Veronica chamaedrys L. & Plantaginaceae & $\mathrm{Y}$ & $\mathrm{N}$ \\
\hline Veronica longifolia L. & Plantaginaceae & $\mathrm{N}$ & $\mathrm{Y}$ \\
\hline Viola mirabilis L. & Violaceae & $\mathrm{Y}$ & $\mathrm{N}$ \\
\hline
\end{tabular}

